\title{
Motivasi dan Partisipasi Petani dalam Pengelolaan Hutan Kemiri di Kabupaten Maros Provinsi Sulawesi Selatan
}

\section{Motivation and Participation of Farmers in Managing The Candlenut Forest in Maros District, South Sulawesi Province}

\author{
Adi Riyanto Suprayitno ${ }^{1}$, Sumardjo ${ }^{2}$, Darwis S. Gani ${ }^{2}$, Basita G. Sugihen ${ }^{2}$ \\ ${ }^{1}$ Balai Pendidikan dan Pelatihan Kehutanan Makassar, Sulawesi Selatan \\ 2 Departemen Sains Komunikasi dan Pengembangan Masyarakat, \\ Fakultas Ekologi Manusia, Institut Pertanian Bogor, Bogor
}

\begin{abstract}
The existence of candlenut forest in Maros District, today, is a successfull evidence of farmers living around the forest participation. Farmers around the candlenut forest has participated in managing that forest since 1826 to meet their subsitence need. They use the candlenut fruit to be one of their household income generating. Hence, those farmers have important roles to manage and to keep that forest sustainability. Any activity, including farmers participation, will undergo enthusiatic if there is any motivation within the person doing that activity. The research intended to identify and analize the contribution of farmers' motivation to their participation in managing and utilizing candlenut forest. The data were collected on January-Maret 2010 in Maros District, South Sulawesi Province using some methods: questionnare list, interview, observation, and documents. The data were analyzed using (1) descriptive statistics, and (2) inferensial statistics based on SEM using LISREL 8.70 software programming. The result shows that farmers 'motivation is in the middle level, but their participation in managing and utilizing candlenut forest is categorized in low level. The Farmers' motivation, however, has a positive contribution for increasing farmers participation in managing and utilizing candlenut forest.
\end{abstract}

Keywords: Farmers' motivation, farmers 'partisipation, candlenut forest

\begin{abstract}
Abstrak
Keberadaaan hutan kemiri Kabupaten Maros saat ini merupakan bukti keberhasilan partisipasi petani sekitar hutan. Petani sekitar hutan telah berpartisipasi dalam mengelola hutan kemiri sejak tahun 1826 untuk memenuhi kebutuhan subsisten. Mereka memanfaatkan buah kemiri sebagai salah satu dari sumber pendapatan rumah tangga. Dengan demikian, petani sekitar memiliki peran penting untuk mengelolala dan menjaga keberlanjutan hutan kemiri. Partisipasi petani akan berjalan dengan antusias jika terdapat motivasi dalam dirisetiap petani yang berpartisipasi. Penelitian bertujuan untuk mengidentifikasi dan manganailisissumbangan motivasi petani terhadap partisipasinya dalam mengelola dan memanfaatkan hutan kemiri. Pengumpulan data dilakukan pada Januari - Maret 2010 di Kabupaten Maros Provinsi Sulawesi Selatan menggunkan metode angket, wawancara, observasi dan studi dokumen. Data dianalisa menggunakan (1) statistik desjriptif dan(2) statistik infrerensial menggunakan SEM dengan bantual perangkat lunak LISREL 8.70. Temuan penelitian menunjukkan bahwa pada saat ini motivasi petani tergolong sedang, tetapi partisipasinya tergolong rendah, namun demikian motivasi tersebut memiliki pengaruh positip terhadap partisipasi petani dalam mengelola hutan kemiri.
\end{abstract}

Kata Kunci: Motivasi petani, partisipasi petani, hutan kemiri

\section{Pendahuluan}

Deforestasi hutan Indonesia telah banyak dikemukakan berbagai peneliti dari banyak lembaga penelitian, kalangan lembaga swadaya masyarakat, media massa, maupun pihak pemerintah. Pada tahun 1986, Bank Dunia telah memberikan peringatan atas kondisi hutan di Indonesia bahwa "dalam 40 tahun Indonesia akan menjadi tandus, dan faktor penyebab utamanya adalah praktek penebangan kayu tanpa perhatian" (Fuad dan Maskanah, 2000).
MoF/FAO pada tahun 1991 menyebutkan, bahwa rata-rata laju deforestasi di Indonesia dalam rentang tahun 1982 sampai dengan 1990 adalah 1,3 juta ha per tahun. Fuad dan Maskanah (2000) menyebutkan bahwa pada tahun 30-an tercatat bahwa luas hutan di Indonesia adalah sekitar 144 juta ha dan berkurang menjadi sekitar 119,3 juta ha pada tahun 80 -an. Hal ini berarti dalam rentang waktu selama 50 tahun terjadi pengurangan luasan hutan sebesar $17,15 \%$ (24,7 juta ha) atau setara dengan 490.000 ha per tahun, bahkan menurut Hinrichs et al., (2008) bahwa

${ }^{1}$ Korespondensi penulis 
deforestasi hutan di Indonesia telah mencapai 1,8 juta hektar per tahun.

Penyebab terjadinya deforestasi di Indonesia selain disebabkan oleh faktor alam, disebabkan pula oleh beberapa proyek pembangunan dan pemanfaatan hasil hutan yang tidak terkendali oleh pihak yang tidak bertanggungjawab, ditambah lagi ancaman-ancaman lainnya seperti illegal logging, serta implementasi kebijakan pengelolaan hutan yang tidak berpihak pada kebutuhan dan kepentingan masyarakat lokal. Kebijakan pengelolaan sumberdaya hutan pada masa lalu lebih bertumpu pada paradigma timber based management dimana pengelolaan hutan cenderung berorientasi pada pengeksploitasian hasil hutan berupa kayu yang berbasis pada upaya peningkatan atau pertumbuhan ekonomi. Pengelolaan sumberdaya hutan sebagian diserahkan kepada swasta (pemilik modal besar) dengan harapan terjadi produksi hutan (kayu) melalui mekanisme fragmentasi kawasan hutan dan suntikan investasi oleh swasta. Pada tataran implementasi terjadi praktek marginalisasi pada masyarakat sekitar hutan, peran masyarakat yang tinggal di sekitar hutan lebih banyak dikesampingkan. Masyarakat sekitar hutan yang aktivitas hidupnya sangat bergantung pada keberadaan hutan pada umumnya hanya dijadikan penonton, tidak dilibatkan dalam kegiatan pengelolaan tersebut, bahkan sering keber-adaan masyarakat sekitar hutan dianggap sebagai ancaman. Penikmat utama dari keuntungan pengeksplotasian hutan hanya para pemilik modal besar (capita) tersebut.

Akibatnya, kondisi ketergantungan hidup masyarakat terhadap sumberdaya hutan yang telah berjalan sejak lama, pada akhirnya terhalang oleh kebijakan pembangunan kehutanan tersebut. Sistem perekonomian rakyat yang bersifat subsisten, sistem jaringan keamanan sosial tradisonal, dan nilai-nilai kearifan lokal mulai memudar bahkan hilang. Sebagian besar masyarakat sekitar hutan akhirnya terasing dan terpinggirkan dari arena pengelolaan hutan. Fakta menunjukkan bahwa pengelolaan hutan berbasis pemerintah dan privatisasi pengelolaan kawasan hutan dalam bentuk pemberian konsesi HPH kepada swasta atau pemilik modal besar ternyata memperlihatkan kegagalan pengelolaan hutan bahkan menimbulkan kerusakan hutan yang terjadi secara sistematis, karena adanya pengeksploitasian kayu yang tidak taat azas.

Pengalaman masa lalu tersebut menyadarkan pemerintah untuk dapat menggeser paradigma lama pengelolaan hutan. Pemerintah menyadari bahwa masyarakat sekitar hutan merupakan ujung tombak bagi kelestarian hutan. Perilaku positip masyarakat dalam berinteraksi dengan hutan dapat menjaga eksistensi hutan. Ide melibatkan masyarakat dalam pengelolaan hutan, sesungguhnya muncul sejak tahun 1978, ketika diselenggarakan Kongres Kehutanan VIII Sedunia di Jakarta dengan tema Forest for People, pelan tapi pasti mulai terjadi pergeseran perspektif tentang peran-peran masyarakat sebagai penanggungjawab pengelolaan hutan di negara-negara yang sedang berkembang. Para penentu kebijakan di seluruh dunia, bukan hanya di Indonesia, secara progresif telah menyadari bahwa pihak yang mengetahui dengan amat baik kondisikondisi hutan setempat tidak lain adalah rakyat yang tinggal dan hidup di kawasan sekitar hutan (Hinrics et al., 2008). Namun demikian, respon terhadap ide tersebut pada tataran implementasinya masih masih terjadi bias dan berjalan lambat.

Pemerintah melalui Kementerian Kehutanan selanjutnya meletakkan paradigma barupembangunan kehutanan yang bertumpu pada sistem pendekatan ekosistem yang dikenal dengan resource based management yang berbasis pada forest community based development (Pusbinluhhut, 2002). Paradigma ini telah memberikan peluang dan ruang gerak yang lebih luas kepada masyarakat sekitar hutan untuk berpartisipasi dalam pengelolaan dan pemanfaatan hutan, di mana masyarakat ditempatkan sebagai salah satu pelaku utama pembangunan. Partisipasi tersebut bukan sekedar masyarakat sebagai pelaksana pembangunan, tetapi menjadi pelaku utama dalam arti keterlibatan masyarakat bersifat menyeluruh yaitu mulai dari perencanaan sampai dengan melakukan evaluasi kegiatan pengelolaan hutan. Partisipasi seperti ini akan menimbulkan rasa memiliki (sense of belonging) dan rasa tanggung jawab (sense of responsibility) terhadap keberhasilan dari kegiatan pengelolaan hutan. Hal ini sejalan dengan pernyataan Craig dan Mayo (1995) bahwa jaminan pembangunan berkelanjutan adalah adanya partisipasi anggotaanggota masyarakat. Program-program pembangunan kehutanan telah menitikberatkan pada pendekatan yang berpusat pada rakyat, artinya masyarakat tidak lagi dilihat sebagai obyek pembangunan, melainkan dilihat sebagai subyek yang aktif yang memiliki inisiatif, kemauan, dan kemampuan dalam mengelola dan melestarikan hutan.

Keberadaan hutan kemiri Kabupaten Maros 
yang tumbuh dan tersebar di sepanjang kawasan Pegunungan Bulusaraung merupakan hasil budidaya tanaman kemiri yang dilakukan petani sekitar hutan secara turun temurun sejak tahun 1826. Hal tersebut merupakan bukti partisipasi dan keberhasilan petani sekitar hutan membangun kebun kemiri sehingga menyerupai bentuk hutan. Dengan kata lain, pengelolaan dan pemanfaatan hutan oleh petani sekitar hutan kemiri Kabupaten Maros merupakan bentuk partisipasi swakarsa dalam membangun hutan, karena motivasi dan inisiasi datangnya dari dalam diri masyarakat petani sendiri.

Suatu pekerjaan atau kegiatan tidak akan berjalan dengan baik apabila tidak disertai motivasi yang tinggi dalam pelaksanaannya, begitu pula dengan kegiatan pengelolaan hutan. Petani sekitar hutan tidak akan mau berpartisipasi apabila tidak memiliki motivasi. Partisipasi yang selama ini telah dilakukan petani sekitar hutan dalam pengelolaan hutan kemiri di Kabupaten Maros, juga, dilandasi oleh adanya motif-motif tertentu yang menjadi pendorong, penggerak, pengarah petani untuk berpartisipasi dan tetap mempertahankan partisipasinya, sebagaimana dikemukan oleh Slamet (2003) bahwa salah satu syarat untuk tumbuhnya partisipasi masyarakat, adalah adanya kemauan dari masyarakat.

Konsep keinginan atau kemauan berkaitan erat dengan konsep motivasi. Thoha (1999) dan Handoko (1997) mengemukakan bahwa terkadang istilah motivasi dipakai silih berganti dengan istilah kebutuhan (need), keinginan (wantwish/will), dorongan (drive), desakan (urge) atau impuls. Petani yang mempunyai motivasi, dengan demikian, akan bersedia mencurahkan energi fisik dan mentalnya untuk berpartisipasi dalam pengelolaan hutan kemiri, sebagaimanan dinyatakan oleh Thoha (1999) bahwa selain terletak pada kemampuannya, orang bekerja juga bergantung pada motivasi dan kekuatan yang dikandung oleh motivasi tersebut. Hal ini berarti bahwa individu yang sangat termotivasi akan melaksanakan upaya substansial, guna mendukung tujuan-tujuan produksinya. Individu yang tidak termotivasi, hanya memberikan upaya minimum dalam hal bekerja, begitu pula partisipasi petani dalam pengelolaana hutan kemiri.

Motivasi dan partisipasi petani sesungguhnya dapat menjadi dukungan yang sangat berarti bagi terpeliharanya hutan kemiri. Ironisnya, pada saat ini, sedang terjadi penurunan kualitas hutan kemiri, yang ditandai komposisi tegakan yang tidak ideal yaitu didominasi oleh tegakan kemiri berusia tua, yaitu rata-rata 56 tahun sehingga mengancam kelestarian dan kesinambungan produktivitas tanaman kemiri yang dapat berdampak pada kesejahteraan petani. Fenomena ini mengindikasikan partisipasi petani yang sejak lama telah berjalan sedang terdegradasi. Mengingat pentingnya motivasi petani dalam mendorong dan mempertahankan partisipasi petani sekitar hutan kemiri dalam mengelola hutan kemiri, maka dirumuskan masalah penelitian yaitu sejauhmana motivasi petani sekitar hutan memberikan pengaruh pada tingkat partisipasinya dalam pengelolaan hutan kemiri. Tujuan penelitian ini adalah mengidentifikasi dan menganalisis pengaruh motivasi petani sekitar hutan terhadap partisipasinya dalam pengelolaan hutan kemiri.

\section{Metode Penelitian}

Desain penelitian yang digunakan adalah $e x$ post facto. Desain penelitian ex post factodigunakan untuk menjajagi kemungkinan hubungan kausalitas (sebab-akibat) di antara variabel bebas dan variabel terikat tanpa adanya manipulasi atau perlakuan dari peneliti terhadap variabel terikat (Kountor, 2006; Hadjar, 1996; Sevilla et.al., 1993). Lokasi penelitian adalah desa-desa yang berada di sekitar hutan kemiri kawasan pegunungan Bulusaraung di tiga kecamatan di kabupaten Maros Provinsi Sulawesi Selatan. Pemilihan lokasi dilakukan secara purposive dengan pertimbangan bahwa hutan kemiri kawasan pegunungan Bulusaraung merupakan areal hutan kemiri terluas di Sulawesi Selatan. Populasi penelitian adalah kepala keluarga/ rumah tangga petani yang lahan dan/atau menggarap hutan kemiri dengan jumlah 10.091 jiwa. Jumlah sampel penelitian sebanyak 204 kepala rumah tangga (berdasarkan rumus rumus slovin dengan presisi $8 \%$ diperoleh jumlah sampel 154 kepala keluarga). Pemilihan sampel dilakukan secara acak proporsional (proporsionate random sampling). Pengumpulan data primer dilakukan dengan cara pengisisan kuesioner, wawancara dan observasi langsung. Data sekunder diperoleh dari berbagai kantor/instansi terkait. Pengolahan dan analisa data menggunakan (1) statistik deskriptif, dan (2) statistik inferensial (SEM dengan menggunakan software 
LISREL 8.70).

\section{Hasil dan Pembahasan}

\section{Sejarah Pengelolaan Hutan Kemiri Rakyat}

Awal mula pembangunan dan pengelolaan hutan kemiri di Kabupaten Maros oleh petani sekitar hutan terjadi pada saat pemerintah Hindia Belanda (VOC) berkuasa di Indonesia yaitu pada abad XIX tepatnya sejak tahun 1826. Pengembangan dan pengelolaan hutan kemiri dilakukan oleh masyarakat suku Bugis yang bermigrasi dari kerajaan Bone dengan membawa bekal tanaman kemiri sebagai hasil hubungan baik dengan VOC. Migrasi dalam jumlah besar ini dipimpin oleh putra Raja Bone XXVII dengan tujuan utama melakukan kerjasama perdagangan dengan VOC dalam bentuk penanaman kemiri pada lahan yang telah ditentukan dan disepakati. Produksi kemiri tersebut, kemudian, diekspor ke negeri Belanda dalam rangka memenuhi kebutuhan konsumsi rempah-rempah Eropa pada saat itu.

Bersama dengan penduduk asli, penanaman kemiri (maddare) pada mulanya dilakukan pada lahan dengan topografi berbukit sampai bergunung dengan cara membuka areal hutan dan padang ilalang atau semak belukar, sedangkan pada tanah dengan topografi datar dibuat sawah (menanaman padi) untuk kebutuhan atau konsumsi sendiri/ rumah tangga. Penanaman kemiri dilakukan dengan pola tumpang sari dan perladangan berpindah dengan tanaman pokok adalah kemiri dan tanaman semusim sebagai tumpang sari seperti kacang tanah, jagung, cabe, tomat, ubi, jahe, dan pisang. Tanaman kemiri difungsikan sebagai pembatas (lakara) bagi kebun yang ditanami tanaman semusim. Pada per-kembangan selanjutnya tanaman kemiri juga ditanam disekitar di lokasi yang tidak jauh dari tempat tinggal/rumah (di tanah datar).

Tanaman semusim ditanam selama 3-4 tahun. Setelah tanaman kemiri mulai besar dan berproduksi maka pengelolan tanaman semusim dihentikan karena sudah tertutup tajuk kemiri sehingga tidak mungkin lagi dilanjutkan. Selanjutnya dibuka lahan lain dengan pola penanaman yang sama. Begitu pula jika tanaman kemiri tidak produktif lagi, petani melakukan peremajaan (mallolo) dengan pola penanaman yang sama. Pola penanaman ini telah menjamin keberlanjutan pengelolaan hutan kemiri oleh petani sampai tahun1980-an.

Perluasan penanaman kemiri dilakukan pada tahun 1920-an dengan persetujuan dan kesepakatan dengan pihak Belanda. Untuk mengatur ketertiban pengelolaan kawasan hutan kemiri, oleh Pemerintah Belanda dibuat batas kawasan hutan berupa patok batu dan jalan setapak (balatu) yang membatasi antara hutan kemiri yang dikelola oleh rakyat yang berada di bagian bawah bukit dengan hutan alam yang berada di bagian atas bukit. Hutan alam ini tidak boleh dikelola dan dimanfaatkan untuk kepentingan lain.

Kawasan hutan kemiri pegunungan Bulusaraung di Kabupaten Maros secara administrasi pemerintahan terletak di Kecamatan Cenrana, Kecamatan Camba, dan Kecamatan Malawa. Ketiga kecamatan tersebut adalah pemekaran dari Distrik Camba. Luas wilayah ketiga kecamatan tersebut adalah 56,616 Ha, yang secara geografis terletak pada 4045'52" - 505'50" LS dan 119044'30" -119056'00" BT. Berdasarkan persentase luas wilayah Kecamatan terhadap keseluruhan luas Kabupaten Maros, maka persentase luas wilayah Kecamatan Cenrana terhadap keseluruhan luas Kabupaten Maros adalah 11\%, Kecamatan Camba adalah 9\% dan Kecamatan Malllawa sebesar 14\%.

Menurut Dinas Kehutanan dan Perkebunan Maros (2009), total luas hutan kemiri dari ketiga wilayah kecamatan tersebut adalah $9.341 \mathrm{Ha}$, dengan ketinggian dari permukaan laut $300-1.200$ meter, dimana Kecamatan Mallawa adalah yang terluas hutan kemirinya yaitu 5.056 Ha, sedangkan Kecamatan Cenrana adalah 2.070 Ha dan Kecamatan Camba seluas 2.215 Ha. Keadaan topografi secara makro bervariasi mulai dari datar/landai sampai dengan bergunung. Sebagian besar (58\%) wilayah tersebut memiliki kelerengan curam, sedangkan hanya $28,1 \%$ yang memiliki kelas lereng landai sampai dengan bergelombang. Batas-batas wilayah administrasi kawasan hutan kemiri adalah di sebelah utara dan timur berbatasan dengan Kabupaten Bone, di sebelah barat berbatasan dengan Kecamatan Bantimurung, dan di sebelah selatan berbatasan dengan Kecamatan Tompobulu.

\section{Keadaan Iklim}

Kawasan hutan kemiri di Kabupaten Maros 
Jurnal Penyuluhan, September 2012 Vol. 9 No. 2

Tabel 1 Jumlah Penduduk di Sekitar Kawasan Hutan Kemiri Kabupamen Maros

\begin{tabular}{clcccc}
\hline No & Kecamatan & $\begin{array}{c}\text { Jumlah Penduduk } \\
\text { (jiwa) }\end{array}$ & $\begin{array}{c}\text { Jumlah Rumah } \\
\text { Tangga }\end{array}$ & Luas $\left(\mathbf{k m}^{2}\right)$ & $\begin{array}{c}\text { Kepadatan (jiwa/ } \\
\left.\mathbf{k m}^{2}\right)\end{array}$ \\
\hline 1 & Cenrana & 14.339 & 3.646 & 180,97 & 79 \\
2 & Camba & 14.315 & 3.551 & 145,36 & 98 \\
3 & Mallawa & 11.892 & 2.994 & 235,92 & 50 \\
\hline
\end{tabular}

Sumber: (1) Kabupaten Maros dalam Angka, 2009

(2) Kecamatan Cenrana dalam Angka, 2009

(3) Kecamatan Camba dalam Angka, 2009

(4) Kecamatan Mallawa dalam Angka, 2009

memiliki tipe iklim $\mathrm{C}$ atau agak basah. Hal ini terutama didasarkan atas indikator rata-rata jumlah bulan kering dan bulan basah, dimana tercatat rata-rata tiga bulan kering, satu bulan lembab dan delapan bulan basah. Curah hujan rata-rata tahunan berkisar antara $2000-3000 \mathrm{~mm} / \mathrm{th}$. Jumlah curah hujan yang terjadi setiap bulannya menyebar. Pada bulan Januari merupakan bulan terbasah, sedangkan bulan September merupakan bulan kering. Pada bulan Nopember curah hujan menanjak naik hingga mencapai puncak tertinggi pada bulan Januari (Stasiun Klimatologi Kabupaten Maros, 2009).

\section{Penduduk}

Jumlah penduduk pada desa-desa di sekitar kawasan hutan kemiri sebanyak 39.058 jiwa. Sebaran penduduk pada ketiga kecamatan tersebut adalah 14.339 jiwa di Kecamatan Cenrana dengan kepadatan penduduk 79 jiwa $/ \mathrm{km}^{2}, 14.315$ jiwa di Kecamatan Camba dengan kepadatan penduduk sebesar 98 jiwa $/ \mathrm{km}^{2}$. Kecamatan Mallawa memiliki jumlah penduduk sebanyak 11.892 jiwa dengan kepadatan penduduk 50 jiwa $/ \mathrm{km}^{2}$.

\section{Sarana dan Prasarana}

Sarana dan prasarana transportasi merupakan elemen yang sangat penting karena dapat memberikan kemudahan pemasaran hasil produksi pertanian ke daerah lain atau ke kota. Oleh karena itu, ketersediaan sarana dan prasarana merupakan faktor penting dalam mendukung kemajuan suatu daerah. Lokasi ibukota setiap kecamatan dapat ditempuh dengan kendaraan roda dua maupun roda empat dari ibukota kabupaten maupun ke ibukota propinsi melalui jalan poros Maros-Bone.
Desa-desa yang berada disekitar wilayah hutan kemirijuga dapat diakses dengan menggunakan kendaraan roda dua dan beberapa dapat ditempuh dengan kendaraan roda empat karena jalan yang dilalui sebagian sudah diaspal dan sebagian lagi masih berupa jalan pengerasan dari batu gunung, sedangkan akses untuk mencapai kawasan hutan kemiri dapat dilakukan melalui jalan setapak yang selama ini digunakan petani.

Sarana dan prasarana kesehatan berupa Pusat Kesehatan Masyarakat (Puskesmas) sudah terdapat di setiap ibukota kecamatan. Puskesmas yang berada di Kecamatan Camba merupakan Puskesmas dengan fasilitas pelayanan yang paling lengkap dibandingkan dua kecamatan lainnya, karena sudah terdapat fasilitas rawat inap. Terdapat masing-masing satu pasar untuk setiap kecamatan, disamping itu terdapat beberapa pasar desa. Untuk Kecamatan Mallawa yang berbatasan dengan Kabupaten Bone, penduduknya lebih suka berbelanja ke pasar parigi di Bone untuk menjual hasil pertaniannya dan berbelanja keperluan seharihari karena pasar parigi merupakan pasar terbesar di Kecamatan Lappariaja Kabupaten Bone dimana persediaan barang konsumsi lebih lengkap. Pasar Cempaniga di Kecamatan Camba dianggap sebagai pusat pasar untuk tiga kecamatan lainnya karena sering dikunjungi penduduk dari dua kecamatan lainnya, dengan hari pasar dua kali dalam seminggu, sedangkan pasar Bengo dan pasar Mallawa walaupun periode buka pasar juga berlaku dua kali seminggu namun pengunjungnya hanya penduduk setempat.

\section{Tingkat Motivasi Petani Sekitar Hutan untuk Berpartisipasi dalam Pengelolaan Hutan Kemiri}

Motif merupakan sumber dari tindakan yang 
Jurnal Penyuluhan, September 2012 Vol. 9 No. 2

Tabel 2 Jarak Ibukota Kecamatan dari Ibukota Kabupaten dan Ibukota Provinsi

\begin{tabular}{llcc}
\hline Kecamatan & Ibukota Kecamatan & $\begin{array}{c}\text { Jarak dari Ibukota Kabupaten } \\
(\mathbf{k m})\end{array}$ & $\begin{array}{c}\text { Jarak dari Ibukota } \\
\text { Provinsi (km) }\end{array}$ \\
\hline Cenrana & Bengo & 32 & 62 \\
Camba & Cempaniga & 47 & 77 \\
Mallawa & Ladange & 60 & 90 \\
\hline
\end{tabular}

Sumber: $\quad$ (1) Kabupaten Maros dalam Angka, 2009

(2) Kecamatan Cenrana dalam Angka, 2009

(3) Kecamatan Camba dalam Angka, 2009

(4) Kecamatan Mallawa dalam Angka, 2009

bertujuan (Sarwono, 2002). Motif yang menjadi aktif disebut dengan motivasi (Sardiman, 2000). Motif menjadi aktif digerakan atau didorong oleh berbagai faktor yang kemudian menjadi tujuan yang hendak dicapai, baik internal maupun eksternal. Begitupula dengan petani sekitar hutan kemiri di Kabupaten Maros, motivasi untuk tetap mempertahankan keterlibatannnya dalam mengelola hutan kemiri memiliki tujuan yang dalam penelitian ini dibagi menjadi tiga, yaitu untuk meningkatkan pendapatan, untuk mendapatkan pengakuan atas kemampuan yang dimiliki dalam mengelola hutan kemiri, dan untuk melestarikan hutan.

Motivasi petani sekitar hutan kemiri untuk tetap berpartisipasi dalam mengelola dan memanfaatkan hutan kemiri tergolong sedang, terlihat bahwa semua aspek motivasi untuk berpartisipasi berada dalam kategori sedang, yaitu aspek motivasi untuk meningkatkan pendapatan dengan rataan skor 51,1, aspek motivasi untuk mendapatkan pengakuan atas kemampuan mengelola hutan kemiri dengan rataan skor 68,1 dan aspek motivasi untuk melestarikan hutan kemiri dengan rataan skor 71,2 (Tabel 3).

\section{Motivasi untuk Meningkatan Pendapatan}

Peningkatan pendapatan warga dalam rangka memenuhi kebutuhan rumah tangga atau mencapai kesejahteraan yang lebih baik merupakan tujuan dari setiap petani, termasuk petani sekitar hutan kemiri. Motivasi untuk meningkatkan pendapatan pada petani sekitar hutan kemiri, dengan demikian pada umumnya, berada dalam kategori sedang yang ditunjang oleh rataan skor total 51,1 .

Tabel 3 memperlihatkan bahwa sebagian besar responden $(54,9 \%)$ memiliki motivasi rendah,
$23 \%$ memiliki motivasi sedang, dan sisanya $(22,1 \%)$ memiliki motivasi yang tinggi untuk meningkatkan pendapatan melalui pemanfaatan hutan kemiri. Namun bila dilihat secara parsial, terdapat perbedaan nyata motivasi untuk meningkatkan pendapatan di antara petani Kecamatan Mallawa dan dua kecamatan lainnya. Motivasi untuk meningkatkan pendapatan pada responden Kecamatan Mallawa memiliki kategori yang rendah (rataan skor 46), sedangkan dua kecamatan lainnya berada dalam kategori sedang, yang ditunjukkan oleh rataan skor 53,5 untuk Kecamatan Cenrana dan 58,5 untuk Kecamatan Camba.

Hal tersebut menunjukkan bahwa walaupun produktivitas tanaman kemiri mengalami penurunan dan kontribusinya relatif kecil terhadap pendapatan rumah tangga yaitu sekitar 13,85\%, namun petani telah merasakan bahwa selama ini penjualan biji kemiri dapat membantu meringankan dan menambah keuangan rumah tangga, sehingga petani sekitar hutan kemiri masih termotivasi atau berminat untuk tetap mengelola dan memanfaatkan hutan kemiri, dengan kata lain pada saat ini petani masih mengandalkan hasil dari tanaman kemiri sebagai salah satu sumber pendapatan rumah tangga meskipun hanya sebagai unsur penunjang. Disamping itu karena buah kemiri dapat disimpan dalam jangka waktu yang relatif lama (2-3 tahunan), maka pemanenan kemiri bagi petani merupakan salah satu usaha yang berfungsi sebagai tabungan yang sewatu-waktu dapat dijual jika ada kebutuhan biaya.

\section{Motivasi Mendapatkan Pengakuan atas Kemampuan dalam Mengelola Hutan}

Pada umumnya motivasi para petani untuk 
Tabel 3 Sebaran Rataan Skor Tingkat Motivasi Petani untuk Berpartisipasi

\begin{tabular}{|c|c|c|c|c|}
\hline $\begin{array}{l}\text { Tingkat Motivasi Petani untuk Berpartisipasi } \\
\text { dalam Pengelolaan Hutan Kemiri }\end{array}$ & $\begin{array}{c}\text { Kecamatan } \\
\text { Cenrana } \\
(\%)\end{array}$ & $\begin{array}{c}\text { Kecamatan } \\
\text { Camba } \\
(\%)\end{array}$ & $\begin{array}{c}\text { Kecamatan } \\
\text { Mallawa } \\
(\%)\end{array}$ & $\begin{array}{l}\text { Total } \\
(\%)\end{array}$ \\
\hline \multicolumn{5}{|l|}{ Meningkatkan pendapatan } \\
\hline Rendah & 44,5 & 24 & 76 & 54,9 \\
\hline Sedang & 22,2 & 46 & 12 & 23,0 \\
\hline Tinggi & 33,3 & 30 & 12 & 22,1 \\
\hline Rataaan Skor & 53,5 & $58,9^{(\mathrm{a})}$ & $46^{(\mathrm{a})}$ & 51,1 \\
\hline \multicolumn{5}{|l|}{$\begin{array}{l}\text { Mendapatkan pengakuan atas kemampuan } \\
\text { mengelola hutan kemiri }\end{array}$} \\
\hline Rendah & 48,1 & 12 & 29 & 29,9 \\
\hline Sedang & 20,4 & 20 & 34 & 27,0 \\
\hline Tinggi & 31,5 & 68 & 37 & 43,1 \\
\hline Rataaan Skor & $60,8^{(\mathrm{a})}$ & $78,3^{(\mathrm{a})}$ & 66,8 & 68,1 \\
\hline \multicolumn{5}{|l|}{ Melestarikan Hutan } \\
\hline Rendah & 42,6 & 12 & 8 & 18,1 \\
\hline Sedang & 31,5 & 32 & 59 & 45,1 \\
\hline Tinggi & 25,9 & 56 & 33 & 36,8 \\
\hline Rataaan Skor & $61,9^{(\mathrm{a})(\mathrm{b})}$ & $77,2^{(\mathrm{a})}$ & $73,3^{(\mathrm{b})}$ & 71,2 \\
\hline
\end{tabular}

Sumber: $\quad$ Analisis Data Primer, 2010

Keterangan: $\sum$ Cenrana $=54 ; \sum$ Camba $=50 ; \sum$ Mallawa $=100$

(a)(b); hasil uji beda dengan ANAVA pada $\alpha=5 \%$

Kategori; Rendah = skor $0-50$

Sedang $=$ skor $51-75$

Tinggi $=$ skor $76-100$

mendapatkan pengakuan dari pemerintah atas kemampuannya mengelola hutan kemiri berada dalam kategori sedang, dengan rataan skor total 68,1. Tabel 3 memperlihatkan bahwa sebagian besar respondem $(43,1 \%)$ memiliki motivasi yang tinggi, 27\% responden memiliki motivasi sedang, dan sisanya (29,9\%) memiliki motivasi yang rendah untuk diakui kemampuannya oleh pemerintah dalam mengelola hutan kemiri. Walaupun berdasarkan perolehan rataan skor motivasi responden untuk mendapat pengakuan dari masing-masing kecamatan berada dalam kategori sedang namun secara statistik terdapat perbedaan nyata motivasi antara responden Kecamatan Cenrana dan responden Kecamatan Camba. Jika dilihat dari rataan skor tiap-tiap kecamatan maka dapat diurut-kan motivasi untuk mendapat pengakuan atas kemampuan dari yang tertinggi ke terendah yaitu Kecamatan Camba dengan rataan skor motivasi 78,3, Kecamatan
Mallawa dengan rataan skor 66,8 , dan Kecamatan Cenrana dengan rataan skor 60,8 .

Motivasi untuk mendapatkan pengakuan dari pemerintah atas kemampuan dalam mengelola hutan kemiri, sebenarnya dipengaruhi oleh faktor historis bahwa terbentuknya kebun kemiri sehingga kualitasnya tampilan-nya menyerupai hutan merupakan usaha yang dilakukan oleh petani sekitar hutan secara turun temurun. Bahkan pada tahun 1979-1980-an petani merasakan secara langsung keuntungan besar yang diperoleh dari kemiri yang berproduktivitas tinggi pada saat itu. Fakta tersebut memberi keyakinan pada petani bahwa mereka mampu melakukan praktek pengelolaan hutan kemiri dengan baik. Menurut responden keberadaan hutan kemiri adalah bukti nyata atas kemampuan mereka dalam mengelola hutan kemiri, sehingga mereka memilki keinginan untuk membuktikan bahwa mereka masih tetap mampu melakukan 
Tabel 4 Sebaran Rataan Skor Tingkat Partisipasi Petani dalam Pengelolaan Hutan Kemiri

\begin{tabular}{|c|c|c|c|c|}
\hline $\begin{array}{c}\text { Tingkat Partisipasi Petani Sekitar Hutan dalam } \\
\text { Pengelolaan Hutan }\end{array}$ & $\begin{array}{c}\text { Kecamatan } \\
\text { Cenrana } \\
(\%)\end{array}$ & $\begin{array}{c}\text { Kecamatan } \\
\text { Camba } \\
(\%)\end{array}$ & $\begin{array}{c}\text { Kecamatan } \\
\text { Mallawa } \\
(\%)\end{array}$ & $\begin{array}{c}\text { Total } \\
(\%)\end{array}$ \\
\hline \multicolumn{5}{|l|}{ Merencanakan Kegiatan Pengelolaan Hutan } \\
\hline Rendah & 100 & 100 & 100 & 100 \\
\hline Sedang & 0 & 0 & 0 & 0 \\
\hline Tinggi & 0 & 0 & 0 & 0 \\
\hline Rataaan Skor & $17,2^{(\mathrm{a})(\mathrm{b})}$ & $3,7^{(\mathrm{a})(\mathrm{c})}$ & $0,7^{(\mathrm{b})(\mathrm{c})}$ & 5,8 \\
\hline \multicolumn{5}{|l|}{ Melaksanakan Kegiatan Pengelolaan Hutan } \\
\hline Rendah & 88,9 & 76 & 97 & 89,7 \\
\hline Sedang & 11,1 & 24 & 3 & 10,3 \\
\hline Tinggi & 0 & 0 & 0 & 0 \\
\hline Rataaan Skor & $32,3^{(a)(b)}$ & $42,6^{(\mathrm{a})}$ & $42,2^{(\mathrm{b})}$ & 39,7 \\
\hline \multicolumn{5}{|l|}{$\begin{array}{l}\text { Memanfaatkan Hasil Kegiatan Pengelolaan } \\
\text { Hutan }\end{array}$} \\
\hline Rendah & 85,2 & 98 & 100 & 95,6 \\
\hline Sedang & 14,8 & 2 & 0 & 4,4 \\
\hline Tinggi & 0 & 0 & 0 & 0 \\
\hline Rataaan Skor & 29,9 & 27,7 & 30,7 & 29,8 \\
\hline \multicolumn{5}{|l|}{$\begin{array}{l}\text { Mengawasi dan Menilai Kegiatan Pengelolaan } \\
\text { Hutan }\end{array}$} \\
\hline Rendah & 98,2 & 100 & 100 & 99,5 \\
\hline Sedang & 1,8 & 0 & 0 & 0,5 \\
\hline Tinggi & 0,00 & 0 & 0 & 0 \\
\hline Rataaan Skor & 9,9 & 14,1 & 10,9 & 11,4 \\
\hline
\end{tabular}

Sumber: $\quad$ Analisis Data Primer, 2010

Keterangan: $\quad \sum$ Cenrana $=54 ; \sum$ Camba $=50 ; \sum$ Mallawa $=100$

(a)(b)(c); hasil uji beda dengan ANAVA pada $\alpha=5 \%$

Kategori: Rendah = skor 0-50

Sedang $=$ skor $51-75$

Tinggi $=$ skor $76-100$

praktek pengelolaan hutan kemiri dengan baik dan benar.

\section{Motivasi Melestarikan Hutan Kemiri}

Motivasi responden untuk melestarikan hutan kemiri, pada umumnya, berada dalam kategori sedang (rataan skor total 71,2). Bila dilihat dari persentase banyaknya responden yang termotivasi untuk melesatrikan hutan kemiri nampak bahwa sebagian besar responden $(45,1 \%)$ memiliki motivasi sedang, 36,8\% responden memiliki motivasi yang tinggi, sisanya $(18,1 \%)$ memiliki motivasi rendah dalam melesatrikan hutan kemiri. Perbedaan nyata motivasi petani untuk melestarikan hutan kemiri terjadi antara Kecamatan Cenrana dan dua kecamatan lainnya. Motivasi tertinggi dimiliki oleh responden di Kecamatan Camba (rataan skor 77,2), diikuti oleh responden Kecamatan Mallawa (rataan skor 73,3), dan responden yang terendah motivasinya untuk melestarikan hutan adalah responden di Kecamatan Cenrana (rataan skor 61,9), namun demikian ketiganya masih berada dalam kategori sedang.

Responden menyadari bahwa hutan kemiri perlu dilestarikan agar bisa dinikmati oleh anak cucu. Hal ini terkait dengan kebiasan masyarakat Sulawesi Selatan yaitu memberikan warisan kepada anak cucunya, sebagaimana yang telah mereka 
alami bahwa hutan/tanaman kemiri yang ada sekarang merupakan warisan dari orang tua mereka. Walaupun kontribusinya kecil, namun selama ini responden telah merasakan manfaat hutan kemiri bagi perekonomian rumah tangga mereka. Apabila hutan kemiri rusak, sedikit banyak akan mengganggu pendapatan rumah tangga. Responden juga memahami bahwa hutan kemiri dapat menjaga kesimbangan ekologi sekitarnya terutama untuk menjaga tata air sungai Walanae. Menurut responden hutan kemiri memiliki nilai historis, sehingga secara psikologis ada ikatan antara mereka dengan keberadaan hutan kemiri. Pengelolaan hutan kemiri yang telah dilakukan secara turun temurun telah menciptakan interaksi dinamis dan harmonis di antara petani sekitar hutan dalam bentuk kelembagaan masyarakat atau kearifan lokal, sehingga eksistensi hutan harus tetap dipertahankan.

\section{Tingkat Partisipasi Petani Sekitar Hutan dalam Pengelolaan Hutan}

Partisipasi merupakan sebuah bentuk keterlibatan aktif masyarakat dalam suatu kegiatan atau program pembangunan. Inisiatif kegiatan atau program dapat berasal dari luar masyarakat atau muncul dari dalam masyarakat itu sendiri. Sardjono (2004) mengemukakan bahwa partisipasi masyarakat merupakan suatu proses dimana masyarakat dilibatkan pada setiap tahap situasi yang berpengaruh terhadap kehdupan mereka. Maksud dari partisipasi adalah untuk mendorong kemandirian masyarakat sehingga tercapai pembangunan yang berkelanjutan (sustainable development).

Tingkat partisipasi sekitar hutan dalam pengelolaan hutan kemiri tergolong rendah. Terlihat bahwa semua aspek partisipasi yaitu merencanakan kegiatan pengelolaan hutan kemiri, aspek melakukan kegiatan pengelolaan hutan kemiri, aspek menikmati dan/atau memanfaatkan hasil kegiatan pengelolaan hutan kemiri, dan aspek mengawasi dan merencanakan kegiatan pengelolaan hutan yang kesemuanya tergolong rendah (Tabel 4).

\section{Merencanakan Kegiatan Pengelolaan Hutan Kemiri}

Perencanaan merupakan langkah awal yang penting bagi keberhasilan suatu kegiatan. Perencanaan yang baik dan sistematis dapat memberikan arah dan menjadi pedoman bagi berlangsungnya suatu kegiatan. Setyowati dan Suporahardjo (2008) bahwa apabila pengelolaan hutan tidak dirancang dengan baik dalam rangka menjamin akses kelola dan manfaat dari hasil hutan, maka akan menjadi beban baru bagi petani lokal. Oleh karena itu, agar kegiatan pengelolaan hutan dapat berjalan dengan lancar, efisien dan efektif, maka kegiatan pengelolaan hutan perlu direncanakan dengan baik.

Partisipasi seluruh responden (100\%) pada aspek perencanaan pengelolaan hutan kemiri berada dalam kategori rendah. Hal ini didukung oleh nilai rataan skor total 5,8. Terdapat perbedaan nyata partisipasi responden pada aspek perencanaan pengelolaan hutan kemiri di antara tiga kecamatan tersebut. Walaupun ketiganya berada dalam kategori rendah, namun apabila diurutkan berdasarkan besarnya nilai rataan skor, maka partisipasi responden Kecamatan Cenrana pada aspek perencanaan pengelolaan hutan kemiri lebih tinggi dibandingkan dua kecamatan lainnya (rataan skor 17,2), diikuti oleh responden Kecamatan Camba (rataan skor 3,7) dan responden Kecamatan Mallawa (rataan skor $0,7)$.

Menurut responden perencanaan pengelolaan hutan kemiri yang mereka lakukan hanya berdasarkan pengalaman yang tidak dituangkan dalam bentuk tertulis, karena menurut mereka budidaya tanaman kemiri adalah kegiatan yang tidak rumit. Proses budidaya kemiri sangat mudah dan tidak membutuhkan perlakuan yang istimewa. Biji kemiri cukup ditanam maka akan tumbuh sendiri, disamping itu proses pemeliharaannya tidak membutuhkan pengawasan yang intensif, sehingga tidak perlu repot untuk melakukan perencanaan yang terinci. Buktinya selama ini, menurut responden, tanaman kemiri yang ditanam secara turun temurun tumbuh dengan baik dan hasilnya dapat dilihat yaitu terbentuknya kebun kemiri yang menyerupai hutan. Hal ini yang meng-akibatkan rendahnya aspek perencanaan pengelolaan hutan kemiri untuk lingkup pengelolaan skala mikro (rumah tangga).

Untuk lingkup perencanaan pengelolaan hutan kemiri pada level yang lebih tinggi (makro), responden menyatakan mereka tidak pernah terlibat atau dilibatkan. Menurut responden, mereka tidak pernah mendapat undangan dari pihak pemerintah (Dishut dan/ atau TN) untuk mengikuti pertemuan dalam rangka merencanakan pengelolaan hutan 
kemiri. Bagi responden apabila pertemuan untuk perencanaan pengelolaan hutan ada dan melibatkan petani, merupakan hal yang bagus, karena dapat menjadi wadah bagi mereka untuk menyampaikan aspirasi dan pertanyaan yang berkaitan dengan hakhak mereka atas hutan kemiri.

\section{Melaksanakan Kegiatan Pengelolaan Hutan}

Partisipasi responden pada aspek pelaksanaan kegiatan pengelolaan hutan kemiri, pada umumnya berada dalam kategori rendah yang ditunjukkan oleh nilai rataan skor total sebesar 39,7. Sebagian besar responden $(89,7 \%)$ rendah pasrtipasinya dalam melaksanakan kegiatan pengelolaan hutan kemiri. Secara statistik, terdapat perbedaan nyata partisipasi pada aspek pelaksanaan kegiatan pengelolaan hutan antara responden Kecamatan Cenrana dan responden pada dua kecamatan lainnya. Bila diurutkan berdasarkan besarnya rataan skor pada masing-masing kecamatan, terdapat kecenderungan bahwa partisipasi responden Kecamatan Camba berada pada urutan terendah dengan rataan skor 32,3. Responden Kecamatan Camba cenderung tertinggi partisipasinya pada aspek pelaksanaan kegiatan pengelolaan hutan dengan rataan skor 42,6, disusul oleh responden Kecamatan Mallawa dengan rataan skor 42,2.

Rendahnya pelaksanaan kegiatan pengelolaan hutan kemiri disebabkan responden tidak melakukan kegiatan perbenihan dan persemaian dengan baik dan benar sesuai dengan kaidah silvikultur, kurang melakukan persiapan lahan untuk penanaman kemiri. Selain itu, responden tidak lagi melakukan penanaman kemiri, kalaupun dilakukan penanaman maka dikerjakan seadanya dengan jarak tanam tidak teratur. Responden tidak pernah melakukan pemupukan pada tanaman kemiri karena biaya pupuk dirasakan mahal, tidak sebanding dengan keuntungan yang diperoleh dari produksi kemiri, disamping itu tanaman kemiri yang ada sekarang ini pada umumnya sudah berusia tua ( $>35$ tahun) sehingga sudah tidak produktif dan tidak lagi memerlukan pupuk. Pemangkasan sebagai wahana memberikan ruang tumbuh bagi tanaman kemiri juga tidak dilaksanakan. Sementara itu penyiangan dilakukan hanya pada masa panen ketika hendak memungut buah kemiri yang jatuh ke tanah. Peremajaan juga tidak dilaksanakan oleh responden, sebagai akibat diberlakukannya Tata Guna Hutan
Kesepakatan (TGHK) sejak tahun 1984, kalaupun ada peremajaan, hal tersebut dilakukan secara sembunyi-sembunyi dengan cara memindahkan atau menggunakan anakan yang berasasal dari suksesi alami.

Gangguan penyakit yang menyerang tanaman kemiri dibiarkan begitu saja oleh responden karena pada kenyataannya mereka tidak mampu melakukan pengobatan. Selain itu, karena bagian tanaman kemiri yang diserang penyakit, baik batang, dahan maupun daun, biasanya berada pada ketinggian sekitar 9-14 meter dari permukaan tanah, sehingga sulit untuk dijangkau. Gangguan hama yang sering terjadi, karena areal tanaman kemiri tidak dipagar, berasal dari babi hutan dan monyet serta ternak sapi yang tidak dikandangkan. Hanya beberapa petani yang memagar kebun kemirinya yang berada di lahan milik, sedangkan yang berada di dalam kawasan hutan tidak dipagari.

Perlindungan hutan sudah tidak terlalu diperhatikan oleh responden karena pada saat ini hutan kemiri sudah tidak menjadi milik mereka lagi, sehingga kegiatan perlindungan yang dilakukan terhadap hutan kemiri tidak optimal, hanya sekedar saja yaitu sebatas menjaga agar buah kemiri yang jatuh ke tanah pada masa panen tidak diambil oleh pihak lain. Beberapa responden melakukan diversifikasi dengan melakukan pengayaan tanaman tanpa menebang pohon kemiri yang ada yaitu menanam pohon coklat dibawah tegakan kemiri di lahan milik.

\section{Memanfaatkan Hasil Hutan}

Besarnya manfaat hutan kemiri yang dapat dirasakan oleh petani akan mempengaruhi keputusan petani untuk berpartisipasi dalam pengelolaannya. Bila petani merasakan bahwa keberdaan hutan kemiri akan bermanfaat baginya, maka mereka akan berpartisipasi dengan semangat dan spontanitas yang besar. Secara umum, partisipasi petani sekitar hutan kemiri Kabupaten Maros dalam memanfaatkan hasil hutan kemiri masuk dalam kategori rendah yang ditandai dengan rataan skor total sebesar 29,8. Hampir seluruh responden $(99,6 \%)$ rendah partisipasinya dalam menikmati atau memanfaatkan hasil hutan kemiri. Secara statistik, tidak terdapat perbedaan nyata dalam memnfaatkan hasil hutan kemiri di antara petani pada ketiga kecamatan yang 
diteliti.

Rendahnya kemampuan responden menikmati atau memanfaatkan hasil hutan kemiri karena yang dimanfaatkan petani hanya berupa pemanenan atau pemungutan buah kemiri yang jatuh ke tanah. Petani tidak melakukan pemetikan karena pada umumnya tinggi pohon kemiri dapat mencapai 40 meter dengan panjang batang bebas cabang 9-14 meter. Artinya, cabang atau ranting terdekat dari sebuah pohon kemiri dimana pada cabang atau ranting tersebut terdapat buah kemiri yang masak tingginya mencapai 9-14 meter, sehingga menurut petani lebih mudah atau praktis memungut buah masak yang jatuh ke tanah.

Selain itu, menurunnya produktivitas kemiri berpengaruh pada pola pemanfaatan buah kemiri yang dipungut, yaitu penjualan biji kemiri cenderung tidak dilakukan setiap tahun. Biasanya petani mengumpulkan selama 2-3 tahunan agar jumlah buah yang terkumpul cukup banyak atau digunakan sebagai tabungan. Pada saat ini, pemanfaatan buah kemiri cenderung hanya untuk keperluan rumah tangga. Pemanfaatan buah kemiri masih dalam bentuk penjualan biji, belum dilakukan upaya membuat turunannya atau mengolah kemiri menjadi bahan jadi, misalnya dalam bentuk produk minyak gosok. Dengan kata lain, belum ada home industry untuk membuat produk turunan dari buah kemiri agar memiliki nilai jual yang lebih baik.

Selain buah beberapa petani memanfaakan ranting-ranting pohon kemiri untuk keperluan kayu bakar, karena tidak semua petani menggunakan kompor minyak tanah danh/atau gas LPG. Pemanfaatan kayu kemiri masih dalam skala terbatas, cenderung untuk keperluan pribadi yaitu digunakan untuk bantalan (berbentuk balok) rumah. Hal ini dilakukan oleh petani yang tidak memiliki banyak modal untuk membeli papan atau balok/ bantalan sebagai bahan atau material membangun rumah. Kayu kemiri termasuk kayu kelas kuat IV (tidak awet) sehingga daya tahannya hanya sekitar satu tahunan. Pada saat ini, walaupun harganya tidak tinggi, sudah ada permintaan pasar terbatas terhadap kayu kemiri. Kayu kemiri yang dijual dalam bentuk bantalan (balok) atau papan, namun petani tidak bisa memanfaatkan hasil hutan berupa kayu kemiri tersebut, karena tanaman kemiri yang mereka miliki kebanyakan berada dalam kawasan hutan. Petani tidak diperbolehkan oleh pemerintah menebang pohon kemiri yang berada dalam kawasan hutan.
Kayu kemiri yang boleh dimanfaatkan oleh petani hanya kayu kemiri yang berada pada lahan milik, namun hal ini tidak banyak dilakukan karena di atas lahan milik petani hanya berisi sedikit tegakan kemiri. Hanya sebagian kecil petani yang menjual kayu kemiri, yaitu petani dimana tanaman kemiri yang dimilikinya tidak jauh dari jalan poros dan mudah dijangkau oleh alat trasportasi sehingga meminimalkan biaya pengangkutan.

\section{Melakukan Kegiatan Monitoring/Pengawasan dan Penilaian}

Keberhasilan suatu kegiatan ditentukan oleh seberapa intensif pengawasan dan penilaian yang dilakukan terhadap kegiatan tersebut sehingga dapat dilakukan perbaikan dengan segera apabila dijumpai kesalahan dalam pelaksanaannya, serta perbaikan untuk kegiatan selanjutnya. Hampir seluruh responden $(99,5 \%)$ rendah partisipasinya dalam melakukan pengawasan dan evaluasi. Dengan demikian dapat dikemukakan bahwa pada umumnya, petani sekitar hutan kemiri memiliki kategori rendah dalam kegiatan pengawasan dan penilaian terhadap pengelolaan hutan kemiri. Hal ini juga ditunjukkan oleh rataan skor total sebesar 11,4. Secara statistik, tidak terdapat perbedaan nyata di antara petani tiga kecamatan yang diteliti dalam kegiatan pengawasan dan penilaian pengelolaan hutan kemiri.

Petani tidak melakukan pengawasan secara rutin dan pencatatan terhadap kesalahan atau halhal yang yang kurang tepat yang dijumpai dalam proses budidaya tanaman kemiri, karena petani menganggap bahwa tanaman kemiri adalah tanaman yang mudah tumbuh dan tahan terhadap serangan penyakit, jadi cukup ditanam dan dibiarkan begitu saja maka akan tumbuh dengan sendirinya. Disamping itu, menurut petani tanaman kemiri yang ada pada saat ini sudah berusia tua ( $>35$ tahun) sehingga tidak perlu dilakukan pengawasan karena sudah tidak produktif. Menurut petani kegiatan yang perlu dilakukan adalah peremajaan/ permudaan atau regenerasi tanaman kemiri.

Penilaian pada akhir masa panen dalam bentuk melakukan pencatatan untuk melakukan perbandingan antara hasil yang diperoleh saat ini dengan hasil sebelumnya dan juga hal-hal yang terkait dengan kesalahan pengelolaan juga tidak dilakukan oleh petani. Selain karena petani sudah 


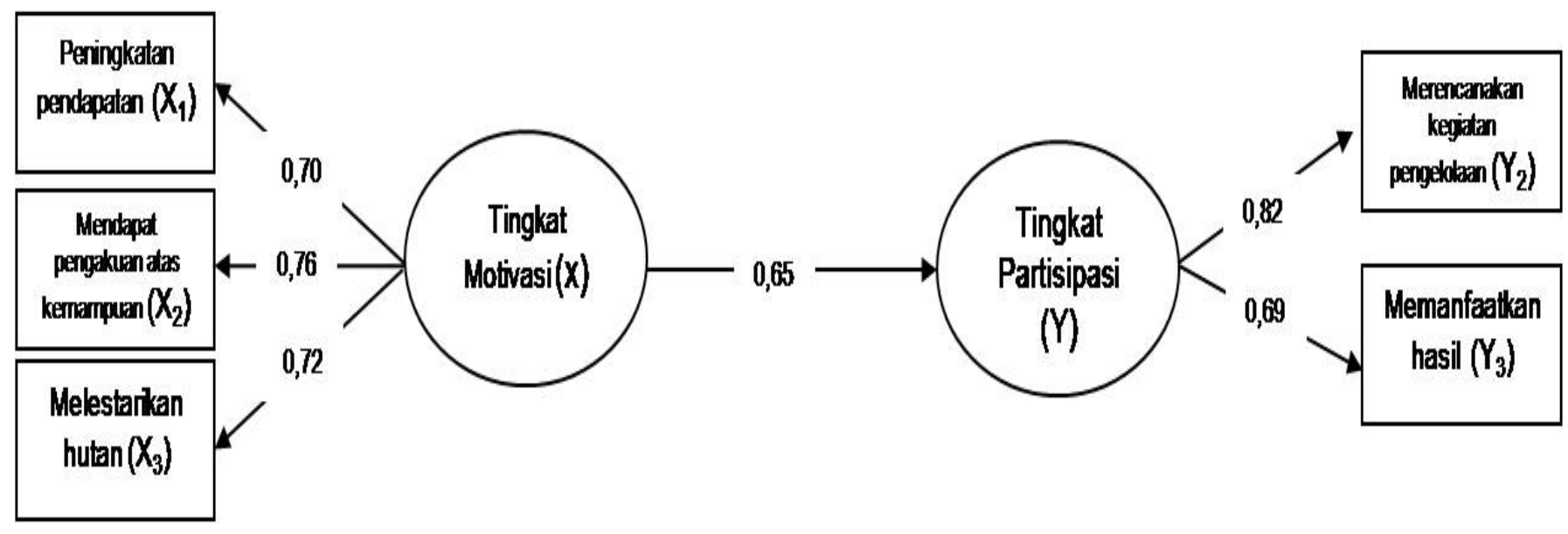

Chi-Square $=182,06, \mathrm{df}=154, \mathrm{p}$-value $=0,06077, \mathrm{RMSEA}=, 0.030, \mathrm{CFI}=0,9782, \mathrm{GFI}=0,9348$

Gambar 2 Model Struktural Pengaruh Motivasi terhadap Partisipasi Petani dalam

Pengelolaan Hutan Kemiri

terbiasa dengan praktek yang dilakukan secara turun temurun dalam bentuk mengelola usahatani secara konvensional/sederhana atau apa adanya yaitu sekedar ditanam, dipanen dan hasilnya dijual tanpa mempertimbangkan kesalahan-kesalahan yang terjadi sehingga perlu perbaikan untuk keberhasilan panen berikutnya, juga karena pada saat ini akses petani terhadap tanaman kemiri yang berada dalam kawasan hutan sudah dibatasi. Rasa memiliki petani terhadap keberadaan pohon kemiri yang ada dalam kawasan sudah luntur sebagai akibat kebijakan TGHK.

\section{Pengaruh Motivasi terhadap Tingkat Partisipasi Petani dalam Pengelolaan Hutan Kemiri}

Berdasarkan analisa SEM menggunakan LISREL8.70, diperolehbahwamotivasiberpartisipasi petani yaitu (1) motivasi untuk meningkatkan pendapatan, (2) motivasi untuk mendapat pengakuan atas kemampuan dalam mengelola hutan kemiri, dan (3) motivasi untuk melestarikan hutan, berpengaruh positip terhadap partisipasi petani sekitar hutan dalam pengelolaan hutan kemiri rakyat (gambar 2). Terlihat bahwa partisipasi petani sekitar hutan kemiri hanya terbatas pada dua aspek (Gambar 2) yaitu aspek melaksanakan kegiatan pengelolaan hutan kemiri dan menikmati atau memanfaatkan hasil dari pengelolaan hutan kemiri. Kondisi ini mencerminkan bahwa partisipasi petani sekitar hutan belum ideal. Hal ini diperkuat dengan fakta penelitian bahwa kedua aspek partisipasi tersebut tergolong rendah.
Berdasarkan analisa SEM yang tertuang pada Gambar 2 dapat dinyatakan bahwa terdapat perbedaan partisipasi antara petani yang motivasinya tinggi dengan petani yang motivasinya rendah. Petani yang memiliki motivasi tinggi akan tinggi pula partisipasinya pada aspek melaksanakan kegiatan maupun menikmati atau memanfaatkan hasil hutan, dengan kata lain semakin tinggi tingkat motivasi petani untuk berpartisipasi dalam pengelolaan hutan kemiri maka akan semakin tinggi tingkat partisipasi petani dalam pengelolaan hutan kemiri.

TemuaninimendukungpendapatSlamet(2003) bahwa partipasi masyarakat dalam pembangunan tidak akan berjalan apabila tidak ada motivasi dalam diri anggota-anggota masyarakat. Motivasi, dengan demi-kian, menjadi penjelas mengapa petani sekitar hutan tergerak untuk berpartisipasi dalam mengelola hutan kemiri tanpa dipaksa. Motivasi tersebut yang mengarahkan, mem-perteguh, dan mempertahankan partisipasi petani dalam mengelola hutan kemiri, sebagimana dinyatakan oleh Cernea (1988) bahwa untuk memahami partisipasi masyarakat tidak cukup dengan melihat aktivitas fisik yang terjadi, melainkan juga perlu untuk melihat motivasi, latar belakang dan proses terjadinya aktivitas tersebut.

Berdasarkan besarnya nilai regresi dapat disusun secara berturut-turut aspek motivasi yang mempengaruhi partisipasi petani yaitu pengaruh terbesar terdapat pada aspek motivasi untuk mendapatkan pengakuan atas kemampuan mengelola hutan, diikuti oleh aspek motivasi untuk melestarikan hutan, dan yang terakhir adalah aspek motivasi untuk meningkatkan pendapatan. 


\section{Motivasi untuk mendapatkan pengakuan atas kemampuan}

Motivasi untuk mendapatkan pengakuan atas kemampuan dalam mengelola hutan kemiri merupakan aspek yang berpengaruh paling besar terhadap tingkat partisipasi petani dalam mengelola hutan kemiri. Semakin tinggi motivasi petani untuk mendapat pengakuan bahwa mereka telah memiliki kemampuan untuk mengelola hutan kemiri dengan baik, maka semakin tinggi tingkat partisipasinya dalam mengelola hutan kemiri. Fakta penelitian menunjukkan bahwa motivasi untuk mendapatkan pengakuan atas kemampuan mengelola hutan kemiri berada dalam kategori sedang. Dengan demkian, temuan ini menjelaskan bahwa petani sekitar hutan kemiri termotivasi untuk tetap dapat berpartisipasi dalam mengelola hutan kemiri didorong oleh keingnan untuk membuktikan bahwa mereka memiliki potensi dan kapasitas yang memadai untuk mengelola hutan kemiri dengan baik.

Rakhmat (2002) menyebut motif ini sebagai motif kompetensi. Rakhmat menjelaskan bahwa setiap orang ingin membuktikan bahwa ia mampu mengatasi persoalan kehidupan apapun. Perasaan mampu tersebut bergantung pada pengalaman, perkembangan kognitif, intelektual, sosial, dan emosional. Hal ini dapat dimaklumi karena petani sekitarhutankemiri, pada umumnya, telahmelakukan praktek pengelolaan hutan kemiri yang dilandasi oleh nilai-nilai budaya dan pengetahuan lokal dalam kurun waktu yang sangat lama dari generasi ke generasi, dengan demikian telah terbentuk dan menyatu dalam diri mereka kemampuan praktis dalam mengelola hutan kemiri. Keberadaan hutan kemiri pada saat ini merupakan bukti nyata bahwa petani sekitar hutan memiliki kemampuan yang dapat diandalkan dalam pengelolaan hutan kemiri, dengan kata lain keberadaan hutan kemiri adalah bukti nyata keberhasilan petani dalam mengelola hutan kemiri.

\section{Motivasi untuk melestarikan hutan kemiri}

Aspek kedua dari motivasi yang berpengaruh positip terhadap tingkat partisipasi petani dalam mengelola hutan kemiri adalah motivasi untuk melestarikan hutan kemiri (Gambar 2). Semakin termotivasi petani sekitar hutan untuk melestarikan hutan kemiri maka akan semakin meningkatkan partisipasinya dalam mengelola hutan kemiri. Temuan ini mendukung temuan penelitianpenelitian terdahulu yang menyatakan bahwa di beberapa daerah di Indonesia terdapat praktekpraktek pengelolaan hutan lestari yang dilakukan oleh masyarakat (Suhardjito dan Darusman, 1998; Suhardjito, 2000; Tadjudin, 2000; Fuad dan Maskanah, 2000; Darusman, 2001; Sardjono, 2004; Wijayanto, 2006). Praktek-praktek pengelolaan hutan tersebut dilandasi oleh kesadaran akan pentingnya hutan yang lestari bagi masa depan kehidupan mereka dan kehidupan banyak orang.

Hal tersebut menjelaskan bahwa apabila dalam diri petani sekitar hutan kemiri terdapat kesadaran akan pentingnya eksistensi hutan kemiri yang lestari maka para petani tetap terdorong untuk menjaganya dan tetap ingin terlibat dalam mengelola hutan kemiri. Kondisi ini didukung oleh fakta penelitian yang menunjukkan bahwa motivasi untuk melestarikan hutan berada dalam kategori sedang. Artinya petani sekitar hutan kemiri, pada dasarnya, telah memiliki kesadaran akan arti pentingnya hutan yang lestari.

Motivasi melestarikan hutan kemiri juga disebabkan secara psikologis petani sekitar hutan merasa memiliki ikatan emosional, historis, dan sosial dengan keberadaan hutan kemiri. Selain itu, disebabkan pula oleh adanya tradisi memberikan atau meninggalkan warisan (mana') berupa lahan sebagai jaminan atau rasa aman bagi kehidupan masa depan anak cucunya. Tradisi ini menjadi salah satu yang menginisiasi timbulnya motivasi untuk melestarikan hutan, sebagaimana dinyatakan oleh Awang (2003) bahwa bagi masyarakat sekitar hutan, hutan dianggap sebagai cadangan lahan untuk keturunan dan masa depan keluaga, dan masyarakat.

\section{Motivasi untuk Meningkatkan Pendapatan}

Aspek motivasi petani berikutnya yang berpotensi memiliki pengaruh terhadap tingkat partisipasi petani dalam mengelola hutan kemiri adalah motivasi untuk meningkatkan pendapatan. Semakin tinggi motivasi petani untuk meningkatkan pendapatan rumah tangganya maka akan semakin tinggi tingkat partisipasi dalam mengelola hutan kemiri. Hutan kemiri yang dikelola oleh petani telah memberikan kontribusi terhadap total pendapatan rumah tangga, walaupun kecil yaitu hanya 13,9\% 
dari total pendapatan. Hal ini oleh petani dirasakan sangat membentu meringankan beban keuangan rumah tangga. Oleh karenanya, petani tetap berminat untuk berpartisipasi dalam mengelola dan memanfaatkannya. Hutan kemiri oleh petani sekitar hutan masih tetap dijadikan sebagai salah satu sumber pendapatan rumah tangga. Hal ini sejalan dengan pendapat Awang (2003) bahwa bagi masyarakat yang tinggal di sekitar hutan, hutan merupakan sumber kehidupan keluarga, hutan juga sebagai penyumbang kayu dan bahan bangunan untuk kepentingan keluarga, dan hutan dapat berperan sebagai faktor produksi.

Produksi buah kemiri bagi petani sekitar hutan selama ini telah dirasakan memberikan jaminan atau kepastian keamanan finansial. Sebagaimana telah disebutkan bahwa buah kemiri dapat disimpan dalam jangka waktu 2-3 tahunan, sehingga dapat berfungsi sebagai tabungan atau cadangan dana yang dapat dijual sewaktu-waktu apabila petani membutuhkan uang. Penelitian yang dilakukan Attar pada tahun 1998 (dalam Suhardjito, 2000) pada hutan rakyat di Kabupaten Wonogiri Desa Sumberejo menunjukkan temuan yang sama dengan temuan penelitian ini bahwa pengelolaan hutan rakyat merupakan usaha yang tetap diusahakan oleh petani dimana hasilnya, walaupun tidak menjadi sumber pendapatan pokok karena kontribusinya yang kecil terhadap total pendapatan rumah tangga, digunakan sebagai tabungan.

\section{Kesimpulan}

Tingkat motivasi petani sekitar hutan untuk berpartisipasi dalam pengelolaan hutan kemiri tergolong sedang, terlihat dari semua aspek motivasi yaitu motivasi untuk meningkatkan pendapatan, motivasi untuk mendapatkan pengakuan atas kemampuan mengelola hutan kemiri, dan motivasi untuk melestarikan hutan yang masuk dalam kategori sedang.

Tingkat partisipasi petani sekitar hutan dalam pengelolaan hutan kemiri tergolong rendah, terbatas pada dua tahapan partisipasi yaitu partisipasi dalam melaksanakan kegiatan pengelolaan hutan kemiri dan partisipasi dalam menikmati atau memanfaatkan hasil hutan, dimana kedua tahapan partisipasi tersebut cenderung rendah. Partisipasi petani sekitar hutan kemiri, dengan demikian, belum ideal atau bersifat parsial.
Tingkat motivasi petani sekitar hutan untuk berpartisipasi, baik aspek motivasi untuk meningkatkan pendapatan, aspek motivasi untuk mendapat pengakuan atas kemampuan mengelola hutan kemir, dan aspek motivasi untuk melestarikan hutan berpengaruh positip terhadap tingkat partisipasi petani sekitar hutan dalam pengelolaan hutan kemiri.

\section{Daftar Pustaka}

Awang SA. 2003. Politik Kehutanan Masyarakat. Yogyakarta (ID): Center for Critical Social Studies \& Kreasi Wacana Yogyakarta.

Cernea MM. 1988. Mengutamakan Manusia Dalam Pembangunan. Jakarta (ID): UI Press.

Craig G, Mayo M. 1995. Community Empowerment: A Reader in Participation and Development. London: Zed Books.

Darusman D. 2001, editor. Resiliansi Kehutanan Masyarakat Di Indonesia. Yogyakarta (ID): Debut Press.

Fuad FH, Maskanah S. 2000. Inovasi Penyelesaian Sengketa Pengelolaan Sumber Daya Hutan. Bogor (ID): Pustaka LATIN.

Handoko T. 1997. Manajemen. Edisi 2.Yogyakarta (ID): BPFE.

Hinrichs A, Muhtaman DR, Irianto N. 2008. Sertifikasi Hutan Rakyat di Indonesia. Jakarta (ID): GTZ.

[Pusbinluhhut] Pusat Bina Penyuluhan Kehutanan 2002. Buku Saku Penyuluhan Kehutanan. Jakarta (ID): Pusbinluhhut, Departemen Kehutanan

Rakhmat J. 2002. Psikologi Komunikasi. Bandung (ID): Remaja Rosdakarya.

Sardiman AM. 2000. Interaksi dan Motivasi Belajar Mengajar. Jakarta (ID): Rineka Cipta.

Sardjono MA. 2004. Mosaik Sosiologis Kehutanan: Masyarakat Lokal, Politik dan Kelestarian Sumberdaya. Yogyakarta (ID): Debut Press.

Sarwono SW. 2002. Psikologi Sosial: Individu dan Teosi-Teosi Psikologi Sosial. Jakarta (ID): Balai Pustaka.

Setyowati AB, Suporahardjo. 2008. Hutan Kemasyarakatan dan Fantasi Hijau Pemerintah Daerah. Studi Kasus: Kabupaten Kuningan, Jawa Barat. Bogor (ID): Pustaka LATIN.

Slamet M. 2003. Membentuk Pola Prilaku Manusia Pembangunan. Bogor (ID): IPB Press. 
Jurnal Penyuluhan, September 2012 Vol. 9 No. 2

Suhardjito D, Darusman D. 1998. Kehutanan Masyarakat: Beragam Pola Partisipasi Masyarakat dalam Pengelolaan Hutan. Yogyakarta (ID): Debut Press.

Suhardjito D. 2000. Hutan Rakyat: Kreasi Budaya Bangsa. Di Dalam Suhardjito D. editor. Hutan Rakyat di Jawa: Perannya dalam Perekonomian Desa. Bogor (ID): P3KM, Fahutan IPB.

Tadjudin D. 2000. Manajemen Kolaborasi. Bogor (ID): Pustaka LATIN.
Thoha M. 1999. Perilaku Organisasi: Konsep Dasar dan Aplikasinya. Jakarta (ID): RajaGrafindo Persada.

Wijayanto N. 2006. Strategi Pengelolaan Hutan Rakyat Lestari. Di Dalam Prosiding Pekan Hutan Rakyat Nasional I: Aktualisasi Peran Litbang Mendukung Hutan Rakyat Lestari. Ciamis (ID): Badan Penelitian dan Pengembangan Kehutanan. 